\title{
Measured and modelled cloud condensation nuclei number concentration at the high alpine site Jungfraujoch
}

\author{
Z. Jurányi, M. Gysel, E. Weingartner, P. F. DeCarlo, L. Kammermann, and U. Baltensperger \\ Laboratory of Atmospheric Chemistry, Paul Scherrer Institut, 5232 Villigen PSI, Switzerland
}

Received: 26 March 2010 - Published in Atmos. Chem. Phys. Discuss.: 7 April 2010

Revised: 26 July 2010 - Accepted: 13 August 2010 - Published: 25 August 2010

\begin{abstract}
Atmospheric aerosol particles are able to act as cloud condensation nuclei (CCN) and are therefore important for the climate and the hydrological cycle, but their properties are not fully understood. Total CCN number concentrations at 10 different supersaturations in the range of $S S=0.12-1.18 \%$ were measured in May 2008 at the remote high alpine research station, Jungfraujoch, Switzerland ( $3580 \mathrm{~m}$ a.s.l.). In this paper, we present a closure study between measured and predicted CCN number concentrations. $\mathrm{CCN}$ predictions were done using dry number size distribution (scanning particle mobility sizer, SMPS) and bulk chemical composition data (aerosol mass spectrometer, AMS, and multi-angle absorption photometer, MAAP) in a simplified Köhler theory. The predicted and the measured CCN number concentrations agree very well and are highly correlated. A sensitivity study showed that the temporal variability of the chemical composition at the Jungfraujoch can be neglected for a reliable CCN prediction, whereas it is important to know the mean chemical composition. The exact bias introduced by using a too low or too high hygroscopicity parameter for $\mathrm{CCN}$ prediction was further quantified and shown to be substantial for the lowest supersaturation.

Despite the high average organic mass fraction $(\sim 45 \%)$ in the fine mode, there was no indication that the surface tension was substantially reduced at the point of $\mathrm{CCN}$ activation. A comparison between hygroscopicity tandem differential mobility analyzer (HTDMA), AMS/MAAP, and CCN derived $\kappa$ values showed that HTDMA measurements can be used to determine particle hygroscopicity required for $\mathrm{CCN}$ predictions if no suitable chemical composition data are available.
\end{abstract}

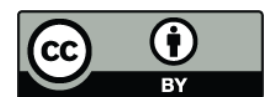

Correspondence to: $\mathrm{M}$. Gysel (martin.gysel@psi.ch)

\section{Introduction}

In the atmosphere, cloud droplets can form when aerosols are exposed to conditions where the air is supersaturated with water vapour. Those aerosol particles that are able to activate and become cloud droplets are commonly referred to as cloud condensation nuclei (CCN). Changes in the number concentration and properties of atmospheric aerosol particles due to anthropogenic emissions result in increased number concentrations of $\mathrm{CCN}$. This increase of $\mathrm{CCN}$ number concentration modifies the microphysical properties of the clouds, thereby causing a radiative forcing (Twomey, 1977; Albrecht, 1989) and influencing our climate (IPCC, 2007).

The critical supersaturation ( $\left.S S_{\text {crit }}\right)$, defined as the supersaturation $(S S)$ at which the cloud droplet activation will take place, is mainly determined by the diameter of the particle at the point of the activation. This activation diameter depends on the dry diameter and the water uptake at RH below activation (hygroscopicity) of the aerosol particle (Köhler, 1936). The equilibrium vapour pressure over a curved pure water surface is elevated, which hinders the CCN activation. The process of activation can also be influenced by surface active species reducing the surface tension (Shulman et al., 1996; Shilling et al., 2007; King et al., 2009) and by compounds with limited solubility. The latter phenomenon can result in exotic equilibrium growth curves (Köhler curves) for aerosol mixtures (Petters and Kreidenweis, 2008). The aerosol mixing state (internally or externally mixed) can also play a role in the CCN activation behaviour of an aerosol population.

Ambient aerosols are mainly composed of complex mixtures (e.g. Krivácsy et al., 2001; Shulman et al., 1996). The main components are inorganic ions, organic components, black carbon and mineral dust (Zhang et al., 2007). The hygroscopicity of single component inorganic aerosols is

Published by Copernicus Publications on behalf of the European Geosciences Union. 
already well characterised (Clegg et al., 1998; Topping et al., 2005; Petters and Kreidenweis, 2007). Single component and mixed organic aerosols have also been studied many times (e.g. Saxena and Hildemann, 1996) but the properties of these mixtures are less understood. Pure black carbon and mineral dust particles are thought to be much less relevant in $\mathrm{CCN}$ activation because they are insoluble and therefore activate at much higher $S S_{\text {crit }}$ (Kuwata et al., 2009; Koehler et al., 2009; Herich et al., 2009). Understanding the activation process of ambient aerosols is a big challenge because it is impossible to get size- and mixing state resolved chemical composition data including complete speciation of all organic compounds.

Examination of the aerosol parameters contributing to $\mathrm{CCN}$ activity, such as size and chemical composition or hygroscopicity, can be used with the existing cloud droplet activation theories to predict $\mathrm{CCN}$ properties and their number concentration for comparison with direct measurements, commonly referred to as CCN closure studies. Such studies provide feedback on how well we understand the activation and water uptake process and to what extent simplifications can be introduced in the models without impairing predictions of CCN number concentrations. Comparison of water uptake on aerosols below saturation with $\mathrm{CCN}$ properties using different parameterisations of the Köhler curve is a common type of a closure study (Kammermann et al., 2010a, and references therein), hereafter referred to as hygroscopicity$\mathrm{CCN}$ closure studies.

Composition-CCN closure studies, which link chemical composition and size distribution of the aerosol with $\mathrm{CCN}$ properties or number concentrations, are a different approach. Several studies appeared in the literature with different methods how they treat the chemical composition and mixing state and with different closure success. The Aerodyne Aerosol Mass Spectrometer (AMS) is most commonly used in CCN closure studies for measuring the chemical composition (Ervens et al., 2007; Cubison et al., 2008; Lance et al., 2009; Broekhuizen et al., 2006; Stroud et al., 2007) but filter measurements are used as well (Liu et al., 1996; Bougiatioti et al., 2009). Ervens et al. (2007) also tried to reach closure between light scattering enhancement factors and $\mathrm{CCN}$ properties.

Numerous simple approaches treat the aerosol composition as a two-component mixture, consisting of a watersoluble inorganic fraction, represented as ammonium sulphate, and a water-insoluble organic fraction (Liu et al., 1996; Gunthe et al., 2009; Broekhuizen et al., 2006). However, several recent studies indicated that a substantial fraction of the organic species is water-soluble, thus also contributing to the reduction of critical supersaturation for $\mathrm{CCN}$ activation (e.g. Moore et al., 2008; Vestin et al., 2007). Bougiatioti et al. (2009) found that including the solubility of organics significantly improved the quality of the prediction by lowering the underprediction of $\mathrm{CCN}$ concentration from $16 \%$ to $0.6 \%$ at their lowest measured SS. The two- component chemical models do not include refractory material such as black carbon, mineral dust, sodium chloride, which is also not measured by the AMS. The potential influence of the insoluble black carbon can be estimated by running a light absorption measurement in parallel to the AMS (Ervens et al., 2010).

The size dependence of the chemical composition and the mixing state - internal versus external mixture - are accounted for in various ways. The simplest approach is to use bulk chemical composition data, which means ignoring the size dependence and assuming internal mixture. Some studies account for the size dependent chemical composition by using size-resolved AMS data (Cubison et al., 2008) or in a simplified form by treating two (or more) size modes with different composition separately (Broekhuizen et al., 2006; Stroud et al., 2007). The common methods for chemical composition measurements do not provide information on the mixing state of the aerosol, however, recent studies by Cubison et al. (2008) and Ervens et al. (2010) tested different assumptions regarding the mixing state of the aerosol. The elemental carbon and/or organic fraction were assumed to be externally mixed with the rest of the aerosol in their calculations. Ervens et al. (2010) compared closure studies from 6 different locations with different distances to the sources. They showed that a fresh pollution aerosol cannot be represented without size resolved chemical composition, but assuming either externally or internally mixed soluble organics leads to similar predictions of $\mathrm{CCN}$ number concentrations.

All above-mentioned closure studies approximate the surface tension of the solution $\left(\sigma_{\mathrm{sol}}\right)$ at the point of activation by the surface tension of pure water. Lance et al. (2009) did calculations using a surface tension that was $0.015 \mathrm{~N} / \mathrm{m}$ lower than for pure water (i.e. $\sigma_{\text {sol }} \approx 0.8 \times \sigma_{\text {water }}$, at a temperature of $20^{\circ} \mathrm{C}$ ) and concluded that $\mathrm{CCN}$ predictions became much worse. The same is true for most hygroscopicity-CCN closure studies, which tend to overpredict rather than underpredict CCN number concentration (Kammermann et al., 2010a).

Looking at the performance of the existing closure studies most of them were able to correctly predict the order of magnitude of the CCN number concentration but for only a few of them the average calculated $\mathrm{CCN}$ number concentration was within $30 \%$ (e.g. Broekhuizen et al., 2006; Kammermann et al., 2010a) and even less achieved very high correlation coefficients (e.g. Bougiatioti et al., 2009). Overall, it appears that with increasing distance from source regions closure is more easily achieved because the aerosol population becomes more homogeneous, i.e. less size dependent, less variable in time and more internally mixed.

Here we present for the first time a $\mathrm{CCN}$ closure study covering a wide range of $S S(0.12 \%-1.18 \%)$ from a remote continental measurement site which is most of the time situated in the free troposphere and only sometimes influenced by injections from the planetary boundary layer (Nyeki et al., 1998). Here we show that highly time resolved aerosol 
Table 1. The used instrumentation and the measured quantities. For detailed description and for meaning of the abbreviations see text.

\begin{tabular}{lll}
\hline Instrument & Manufacturer & Measured property \\
\hline SMPS & TSI, custom made & Size distribution $(12 \mathrm{~nm}<D<570 \mathrm{~nm})$ \\
CPC & TSI & Total particle number concentration \\
OPC & Grimm & Size distribution $(0.3 \mu \mathrm{m}<D<20 \mu \mathrm{m})$ \\
AMS & Aerodyne, Tofwerk AG & Chemical composition \\
MAAP & Thermo ESM Andersen & Black carbon mass concentration \\
HTDMA & Custom made & Hygroscopicity \\
CCNC & DMT & CCN number concentration \\
\hline
\end{tabular}

number size distribution data along with knowledge of the mean chemical composition is sufficient for accurate prediction of CCN number concentrations at all investigated supersaturations. A detailed sensitivity study shows that the variability of chemical composition has little influence on $\mathrm{CCN}$ number concentrations, whereas the variability of the aerosol number size distribution has a bigger influence.

\section{Method}

The Jungfraujoch (JFJ) measurement site is a Global Atmosphere Watch (GAW) station where different aerosol properties have been continuously measured since 1995 (Nyeki et al., 1998; Collaud Coen et al., 2007). The site is situated in the Bernese Alps in Switzerland at $3580 \mathrm{~m}$ a.s.1. Because of its altitude and location it is far away from local pollution and therefore considered as a continental background site. The aerosol shows a strong seasonal variability with higher concentrations in summer and lower concentrations in winter. This is due to the fact that in summer the site is influenced by injections from the more polluted planetary boundary layer because of the stronger thermal convection, while during winter the site mostly stays in the undisturbed free troposphere. A more detailed description of the site can be found elsewhere (Baltensperger et al., 1997).

Measurements were conducted during the EUCAARI (European Integrated Project on Aerosol-Cloud-Climate and Air Quality Interactions) intensive campaign in May 2008 (Kulmala et al., 2009). Air was sampled through a heated $\left(25^{\circ} \mathrm{C}\right)$ inlet in order to evaporate any water that is associated with those aerosol particles that formed cloud droplets or ice crystals. The inlet has been designed such that it samples not only the interstitial aerosols but also the cloud droplets and ice crystals up to $40 \mu \mathrm{m}$. A detailed description of this "total aerosol inlet" is given elsewhere (Weingartner et al., 1999; Henning et al., 2002). Heating the aerosol from $\sim-4.5^{\circ} \mathrm{C}$ (mean outdoor temperature in May 2008) to $\sim 25^{\circ} \mathrm{C}$ lab temperature also dries it to $\mathrm{RH}<10 \%$. All instruments of which data are used in this manuscript were connected to this inlet and are summarized in Table 1 .
The aerosol number size distribution between diameters of 12 and $570 \mathrm{~nm}$ was measured with a scanning mobility particle sizer (SMPS). It consisted of a differential mobility analyzer (DMA, TSI 3071) and a condensation particle counter (CPC, TSI 3772). The size distribution was measured every $6 \mathrm{~min}$, with an up-scan time of $300 \mathrm{~s}$. The DMA was operated with $1 \mathrm{~L} \mathrm{~min}^{-1}$ sample air flow rate and a closed-loop sheath air flow rate of $5 \mathrm{~L} \mathrm{~min}^{-1}$. The sheath flow rate was continuously regulated to a constant volumetric flow, using a mass flow controller with continuously pressure and temperature compensated mass flow set point. All flow rates were regularly checked with a bubble flowmeter. Sizing accuracy was checked by using polystyrene latex (PSL) spheres of different diameters. The peak position agreed within $\pm 3 \%$ with the nominal size of the certified PSL spheres, which is within uncertainty. An identical copy of this SMPS instrument participated in the EUSAAR SMPS intercomparison workshop in 2008 in Leipzig.

The total number particles with diameter larger than $10 \mathrm{~nm}$ $\left(N_{\mathrm{CN}}\right)$ was also monitored by a CPC (TSI 3010). A comparison of the integrated SMPS concentration $\left(N_{12-570}\right)$ with the CPC data revealed that the SMPS number concentration data had to be corrected by a factor of 1.2 (see details in the Appendix). Undercounting of the SMPS was confirmed by further instrument comparisons and may have been caused by slight deviations of the sample and sheath flow rates from the nominal values, or a DMA transfer probability which was lower than assumed.

In addition to the SMPS, an optical particle counter (OPC, Grimm Dustmonitor 1.108) was used to measure the size distribution of the larger particles in the optical diameter range $0.3 \mu \mathrm{m}$ to $20 \mu \mathrm{m}$. In this instrument particles are illuminated by a laser beam, and the scattered light is used to determine their optical size.

An Aerodyne high resolution time-of-flight aerosol mass spectrometer (AMS) was used to measure the size resolved aerosol chemical composition of the non-refractory submicron aerosol particles (DeCarlo et al., 2006; Canagaratna et al., 2007). The aerosol is sampled through an aerodynamic lens which focuses particles between $35 \mathrm{~nm}$ and $1.5 \mu \mathrm{m}$ into a tight beam. After the time of flight sizing the particles impact on an inverted conical tungsten 
vapour, where the non-refractory components are flash vapour. The resulting gas is then ionised by electron ionisation at $70 \mathrm{eV}$. A high mass resolution mass spectrometer (H-TOF, Tofwerk AG, Thun, Switzerland) produces a time series of mass spectra which is processed using custom software (http://cires.colorado.edu/jimenez-group/ ToFAMSResources/ToFSoftware/index.html) to give mass concentrations of non-refractory species. The collection efficiency as determined by intercomparison with other collocated instruments (e.g. SMPS and nephelometer) was found to be 1 at the JFJ for the deployed instrument. The measured ionic species account for $96 \%$ of the total ionic mass at the measurement site (Cozic et al., 2008; Henning et al., 2003), thus the refractory ionic species can be neglected.

The AMS does not detect refractory material such as black carbon (BC), therefore a multi-angle absorption photometer (MAAP, Thermo ESM Andersen) operating at a wavelength of $630 \mathrm{~nm}$ (Petzold and Schonlinner, 2004) was used to measure the $\mathrm{BC}$ mass concentration during the measurement campaign. The MAAP is part of the continuous measurement program of GAW. The absorption values were converted into $\mathrm{BC}$ mass concentration using a mass absorption efficiency of $6.6 \mathrm{~m}^{2} \mathrm{~g}^{-1}$ (Petzold et al., 2005).

Mineral dust is another type of refractory material that is not detected by the AMS. The contribution of this material to the total aerosol number concentration is normally low at our measurement site, though the contribution to the total mass is considerable during Saharan dust events (SDE). The potential influence of neglecting the mineral dust in our CCN predictions is discussed in Sect. 4.8.

A custom built hygroscopicity tandem differential mobility analyzer (HTDMA) based on the instrument presented by Weingartner et al. (2002), was operated to measure the hygroscopic growth factor GF at a constant relative humidity (RH) of $90 \%$ of six different dry diameters $\left(D_{0}=35,50,75\right.$, 110,165 and $265 \mathrm{~nm}$ ). The instrument was designed such that the residence time between the DMAs was $\sim 20$ s; sufficient for most atmospheric aerosols to reach equilibrium at high RH (Sjogren et al., 2007). The HTDMA raw data were corrected against dry GF-offsets by linearly interpolating deviations between two validation sessions, and inverted using the TDMAinv algorithm by Gysel et al. (2009). Only HTDMA data measured at an RH within the range $88 \%<\mathrm{RH}<92 \%$ were used to derive the hygroscopicity parameter $\kappa$ (Petters and Kreidenweis, 2007).

A single-column continuous-flow streamwise thermalgradient CCN chamber (DMT CCNC-100, Roberts and Nenes, 2005) was used to measure the total polydisperse $\mathrm{CCN}$ number concentration as a function of time and supersaturation $(S S)$. The latter is determined by the temperature gradient applied along the wetted wall of the column, where the activation takes place. The particles that have lower $S S_{\text {crit }}$ than the SS in the column will activate and grow into the supermicron size-range. Particles leaving the column are sized by an optical particle counter (OPC) and counted as CCNs if their diameter is larger then a threshold size of typically $1 \mu \mathrm{m}$.

The CCNC was calibrated regularly by using nebulised, size selected (with the DMA) ammonium sulphate particles (Rose et al., 2008). At a certain temperature gradient the DMA size was stepped (D-scans) and the critical dry diameter $\left(D_{0, \text { crit }}\right)$, where $50 \%$ of the singly charged ammonium sulphate particles were activated, was determined by fitting the sum of two sigmoid functions - in order to account for doubly charged particles - to the activation curve. The $S S_{\text {crit }}$ corresponding to $D_{0, \text { crit }}$ was obtained from the ADDEM model (Topping et al., 2005). During calibrations 10 different temperature gradients were set in the CCNC such that the resulting $S S$ values covered the range of $S S=0.07-1.1 \%$. The calibration curve was linear and remained stable during the measurement campaign $\left(S S=0.097 \% K^{-1} \cdot \Delta T-0.139 \%\right.$, where $\Delta T$ is the temperature difference over the column).

The CCNC was operated at a total flow rate of $1 \mathrm{~L} \mathrm{~min}^{-1}$ with a sheath-to-aerosol flow ratio of 10 . One measurement cycle included measurements at 10 different SS $(0.12 \%$ $1.18 \%)$. The CCN concentration at each $S S$ was measured for $3 \mathrm{~min}$, which adds up to a total time of 50-60 $\mathrm{min}$ for the complete cycle including the time required for $S S$ stabilisation at each setpoint.

\section{Theory}

A particle's ability to act as $\mathrm{CCN}$ depends on its chemical composition and size. Both chemical composition and particle number size distribution data are available in this study, which makes an independent calculation of the expected CCN number concentration at a given supersaturation possible. For this purpose the critical dry diameter for CCN activation at a given supersaturation was calculated from the composition data using a simplified Köhler theory.

The equilibrium saturation ratio $S=p / p_{0}$, where $p$ is the partial vapour pressure of water and $p_{0}$ is the saturation vapour pressure of water, over an aqueous solution droplet can be described by the Köhler theory (Köhler, 1936; McFiggans et al., 2006):

$$
S=a_{w} \exp \left(\frac{4 \sigma_{\mathrm{sol}} v_{w}}{R T D_{\mathrm{drop}}}\right)
$$

where $a_{w}$ is the water activity of the solution, $\sigma_{\text {sol }}$ is the surface tension of the solution, $v_{w}$ is the partial molar volume of water in solution, $R$ is the universal gas constant, $T$ is the temperature and $D_{\text {drop }}$ is the droplet diameter.

We used a semi-empirical water activity parameterisation, which was introduced by Petters and Kreidenweis (2007):

$a_{w}=\left(1+\kappa \frac{D_{0}^{3}}{D_{\mathrm{drop}}^{3}-D_{0}^{3}}\right)^{-1}$ 
Table 2. The chemical species, their densities and their $\kappa$ values that were used for our model calculations.

\begin{tabular}{lll}
\hline Component & Density $\left[\mathrm{kgm}^{-3}\right]$ & $\kappa_{i}[-]$ \\
\hline Black carbon & 1770 (Park et al., 2004) & 0 (Weingartner et al., 1997) \\
Organics & 1270 (Cross et al., 2007) & 0.1 (Sjogren et al., 2008; Jurányi et al., 2009) \\
$\left(\mathrm{NH}_{4}\right)_{2} \mathrm{SO}_{4}$ & 1769 & 0.61 (Petters and Kreidenweis, 2007) \\
$\mathrm{NH}_{4} \mathrm{NO}_{3}$ & 1720 & 0.67 (Petters and Kreidenweis, 2007) \\
\hline
\end{tabular}

where $\kappa$ is the hygroscopicity parameter, and $D_{0}$ the dry particle diameter. Substituting $a_{w}$ in Eq. (1) with Eq. (2) provides the $\kappa$-Köhler equation:

$S=\left(1+\kappa \frac{D_{0}^{3}}{D_{\text {drop }}^{3}-D_{0}^{3}}\right)^{-1} \exp \left(\frac{4 \sigma_{\text {sol }} v_{w}}{R T D_{\text {drop }}}\right)$

The $S S_{\text {crit }}$ of a particle with known properties $\left(D_{0}, \kappa, \sigma_{\text {sol }}\right)$ corresponds to the maximum of Eq. (3) with $D_{\text {drop }}$ as the independent variable. The critical dry diameter of a particle, $D_{0 \text {,crit }}$, with known properties $\left(\kappa, \sigma_{\text {sol }}\right)$ and at a given $S S$ is also obtained through Eq. (3) by varying $D_{0}$ until the corresponding $S S_{\text {crit }}$ becomes equal to the given $S S$.

The $\kappa$ parameter of a mixture of $n$ different compounds (or compound classes) is the linear combination of the individual $\kappa_{i}$ in pure form weighted by their respective volume fractions, $\epsilon_{i}$, in the mixed, dry particle:

$\kappa=\sum_{i=1}^{n} \epsilon_{i} \kappa_{i}$

This equation is equivalent to the Zdanovskii-StokesRobinson (ZSR) mixing rule (Stokes and Robinson, 1966).

The volume fractions $\epsilon_{i}$ of the individual components were calculated from the measured mass concentrations, $m_{i}$, and their respective densities, $\rho_{i}$ :

$\epsilon_{i}=\frac{m_{i} / \rho_{i}}{\sum m_{k} / \rho_{k}}$

The $\kappa$ values of ambient aerosol compounds vary between 0 (insoluble, wettable) and $\sim 1.2-1.33$ (pure $\mathrm{NaCl}$ ). Table 2 summarizes the individual species and compound classes along with their properties $\left(\kappa_{i}, \rho_{i}\right)$ that were used in our calculation. Here we use constant $\kappa_{i}$ values, setting aside that $\kappa_{i}$ at the point of $\mathrm{CCN}$ activation may vary with the dry diameter (e.g. for pure ammonium sulphate $\kappa=0.59$ for $D_{0}=50 \mathrm{~nm}$ and $\kappa=0.65$ for $D_{0}=150 \mathrm{~nm}$ ).

The composition-derived $\kappa$ parameter of the mixed atmospheric aerosol was calculated using Eqs. (4) and (5), thereby assuming an internally mixed aerosol and size-independent chemical composition. Justification of the latter assumption is discussed in Sect. 4.2. Using this composition-derived and time-dependent $\kappa$ along with Eq. (3) makes it possible to calculate for the $S S$ set in the CCNC the critical diameter $\left(D_{0, \text { crit }}\right)$. All particles larger than $D_{0, \text { crit }}$ will activate as
$\mathrm{CCN}$, assuming internal mixture. Integrating the size distribution provided by the SMPS from $D_{0 \text {,crit }}$ up to the largest measured size then gives the predicted $\mathrm{CCN}$ number concentration.

We assumed surface tension of pure water in our calculations, even though surface active organic compounds have the potential to lower the surface tension. Potential effects of this assumption are discussed in Sect. 4.5.

\section{Results and discussion}

\subsection{Measured aerosol properties}

All extensive aerosol properties show a strong seasonal variability at the JFJ, with much higher values in summer than in winter (Collaud Coen et al., 2007). From this perspective the month May can be described as an intermediate month with episodes of both undisturbed free tropospheric conditions as well as influence by injections from the planetary boundary layer.

For our $\mathrm{CCN}$ closure experiment we measured the following aerosol properties throughout May 2008: CCN number concentration at different supersaturations as well as dry particle number size distribution and chemical composition. Time series of these measurements are shown in Figs. 13 . Two distinct synoptic conditions were encountered during the measurement period. In the first half and at the very end of the campaign the aerosol number, $\mathrm{CCN}$ and mass concentrations were relatively high, indicating influence of boundary layer injections. Much lower concentrations were observed from 16 to 27 May indicating free tropospheric conditions.

The time series of CCN number concentrations measured at different $S S$ is shown in Fig. 1a. CCN number concentrations varied between 0.1 and $600 \mathrm{~cm}^{-3}$ at $S S=0.12 \%$ (lowest $S S$ ) and between 27 and $1582 \mathrm{~cm}^{-3}$ at $S S=1.18 \%$ (highest $S S$ ) with mean values and standard deviations of $149 \pm 171 \mathrm{~cm}^{-3}$ and $568 \pm 401 \mathrm{~cm}^{-3}$, respectively. Minimum and maximum observed $\mathrm{CCN}$ number concentrations at a certain $S S$ differed by more than two orders of magnitude. Figure $1 \mathrm{~b}$ shows the activated fraction (AF), defined as the ratio of the CCN number concentration (Fig. 1a) to the integrated SMPS number concentration (Fig. 2a). The activated fraction varied by less than a factor of $\sim 4$, indicating that 


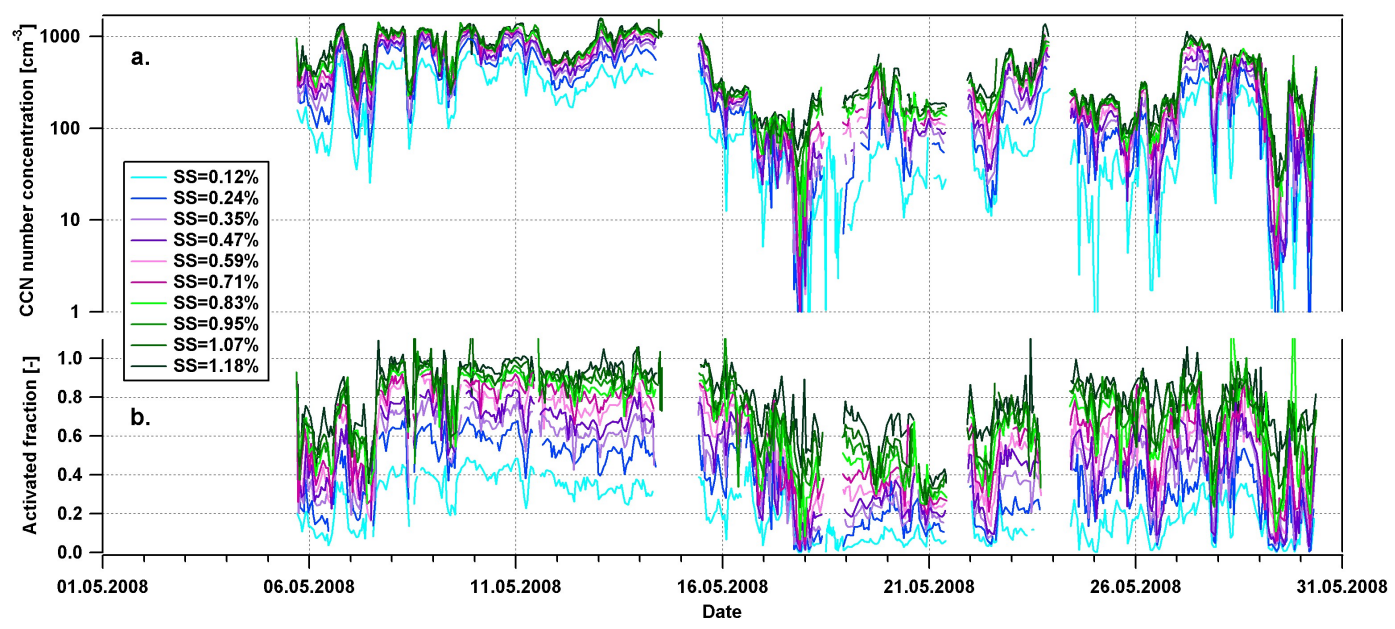

Fig. 1. Time series of (a) $\mathrm{CCN}$ number concentration (note logarithmic ordinate scale) and (b) activated fraction (\#CCN/N $12-570$ ). The different colours represent the different supersaturations $(S S)$.

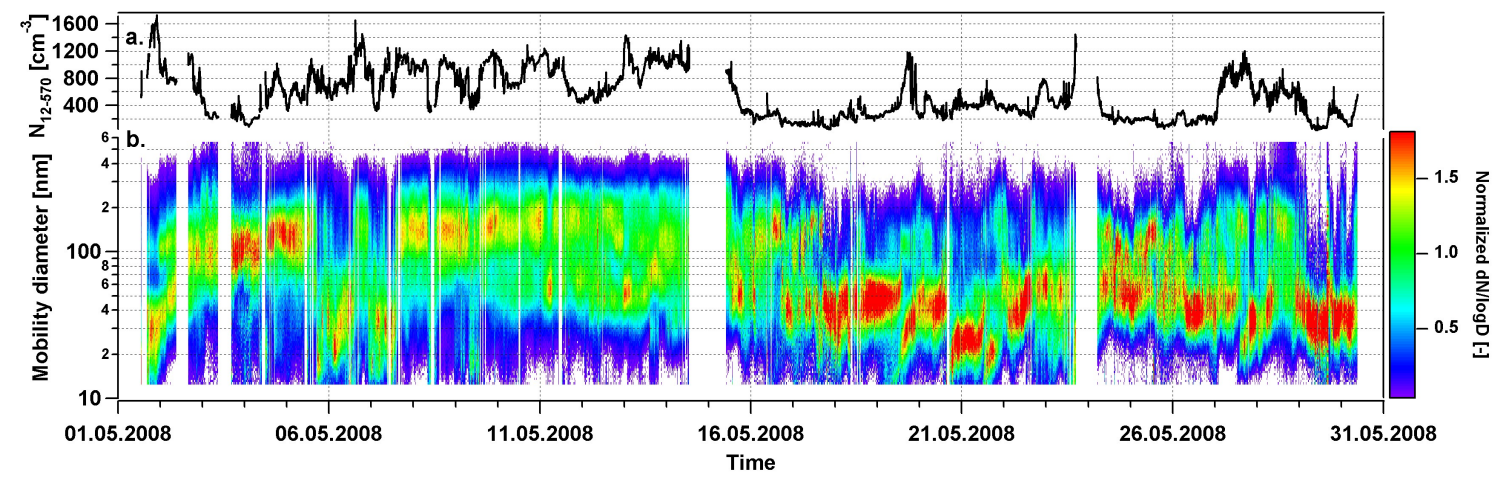

Fig. 2. Size distribution and the integrated number concentration during the measurement campaign. The size distribution was measured by the SMPS between $12 \mathrm{~nm}$ and $570 \mathrm{~nm}$ mobility diameter and normalized with the integrated number concentration.

most of the high variability of $\mathrm{CCN}$ number concentration is due to the variability of the total particle number concentration, while a smaller part of it can be attributed to variations of the aerosol properties such as shape of the size distribution and chemical composition.

Some correlation between the CCN number concentration and the activated fraction was observed for this data set (Fig. 1). Whether this is generally the case will be addressed in a forthcoming manuscript using a separate long-term data set.

In May 2008, the aerosol number size distribution (Fig. 2b, normalised with the integrated concentration) was most of the time monomodal, occasionally bimodal. The geometric mean diameter varied between 28 and $120 \mathrm{~nm}$ with a mean value of $71 \mathrm{~nm}$ and the integrated number concentration varied between 40 and $1720 \mathrm{~cm}^{-3}$ with a mean value of $550 \mathrm{~cm}^{-3}$. Please note, that the average $\mathrm{CCN}$ number concentration at $S S=1.18 \%$ exceeds the average integrated number concentration, this is due to the different time periods over which the averaging was done. A trend towards slightly bigger particle size during the period with influence from the planetary boundary layer compared to the free tropospheric conditions was observed. This is in line with the findings previously reported by Weingartner et al. (1999) based on a whole year of size distribution measurements.

During nucleation events a substantial fraction of the aerosols was possibly present below $12 \mathrm{~nm}$ and was therefore not measured by the SMPS. However this does not affect our calculated CCN number concentration because $D_{0 \text {,crit }}$ at the highest $S S$ was on average at $31 \mathrm{~nm}$ and always above $27 \mathrm{~nm}$. On the other hand, the aerosol particles with diameters larger than $570 \mathrm{~nm}$ are not captured either by the SMPS. These large particles will always act as CCN due to their large dry size, even if they are just slightly hygroscopic (minimum required $\kappa=0.005$ at $S S=0.12 \%$ for a $570-\mathrm{nm}$ particle). However, the OPC measurements show that the number concentration of particles above the upper detection limit of the SMPS is always negligible compared to the number concentration of $\mathrm{CCN}$, even at the lowest applied SS. 


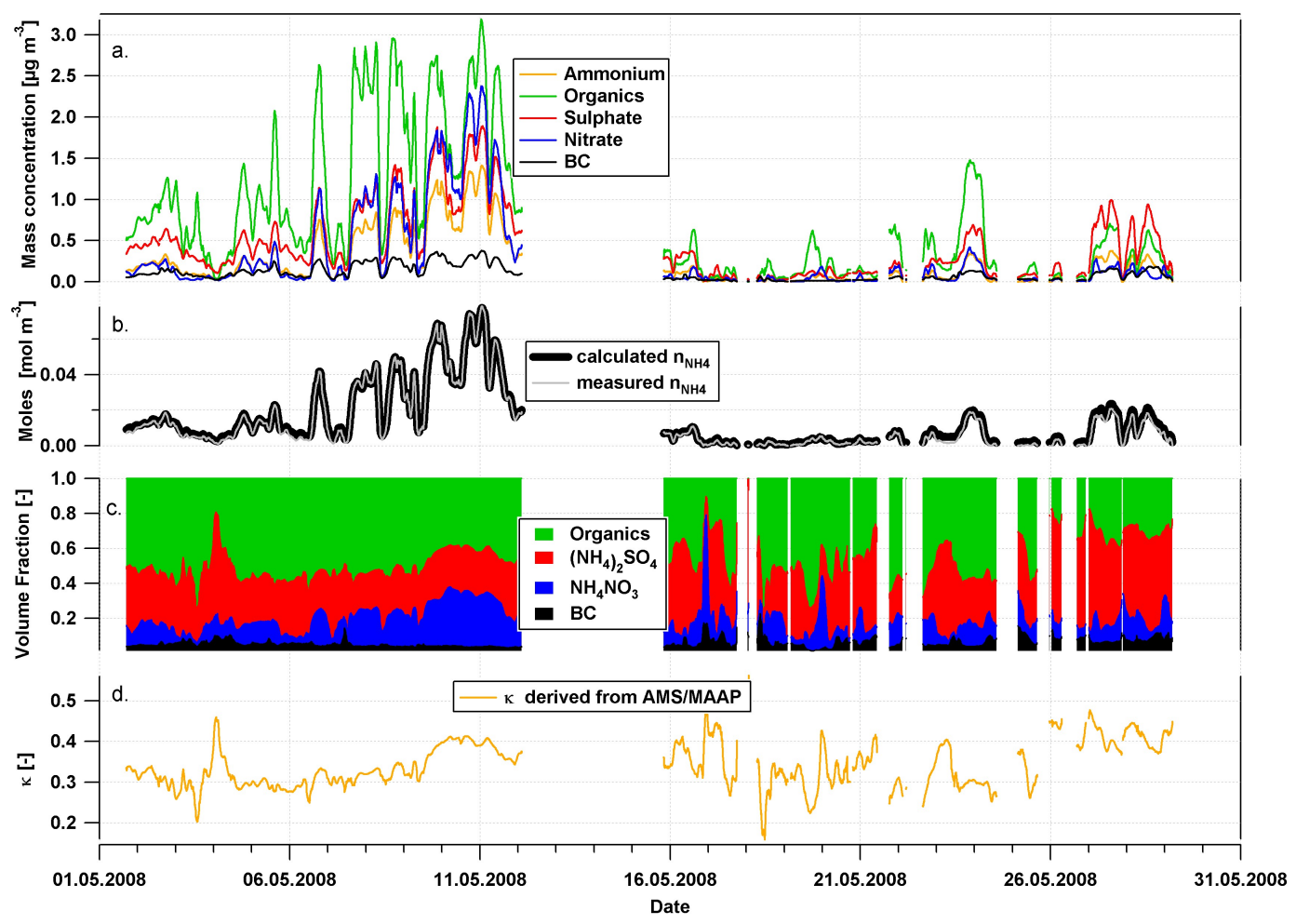

Fig. 3. Chemical composition of the aerosol, measured by the AMS and the MAAP. (a) shows the mass concentration of the individual species using a collection efficiency of 1 in the AMS. (b) shows the molar concentration of the measured $\mathrm{NH}_{4}$ and the amount that is needed for complete neutralization. On (c) the volume fractions of the organics, $\mathrm{NH}_{4} \mathrm{NO}_{3},\left(\mathrm{NH}_{4}\right)_{2} \mathrm{SO}_{4}$ and black carbon are shown; the calculation was done using the density values of $1270 \mathrm{~kg} / \mathrm{m}^{3}, 1720 \mathrm{~kg} / \mathrm{m}^{3}, 1769 \mathrm{~kg} / \mathrm{m}^{3}$ and $1770 \mathrm{~kg} / \mathrm{m}^{3}$, respectively. (d) shows the hygroscopicity parameter $\kappa$ which was calculated from the volume fraction weighted sum of the $\kappa_{i}$ values of the above species.

The bulk mass concentrations of ammonium, sulphate, nitrate and organics as measured by the AMS, are shown in Fig. 3a, along with the BC mass concentrations measured by the MAAP. Due to the low aerosol mass concentrations of the measured species (the mean total mass concentration was $1.93 \mu \mathrm{g} \mathrm{m}^{-3}$ ) averaging to a 2-h running mean was necessary. No substantial size dependence of the chemical composition was observed in the time-averaged AMS data (see also Sect. 4.2). The charge balance based on the ammonium, nitrate and sulphate concentrations revealed that the aerosol was completely neutralised within the detection limits of the AMS (Fig. 3b). Therefore these ions can be paired to $\mathrm{NH}_{4} \mathrm{NO}_{3}$ and $\left(\mathrm{NH}_{4}\right)_{2} \mathrm{SO}_{4}$ for the $\mathrm{ZSR}$ calculations.

Figure $3 \mathrm{c}$ shows the volume fractions of the chemical components, which were calculated from the respective mass fractions using Eq. (5) and the densities listed in Table 2. The average values of the observed volume fractions were: $5.7 \%, 13.3 \%, 33.3 \%, 47.7 \%$ for $\mathrm{BC}, \mathrm{NH}_{4} \mathrm{NO}_{3},\left(\mathrm{NH}_{4}\right)_{2} \mathrm{SO}_{4}$ and organics, respectively. Similar values were found during previous measurement campaigns at the same measurement site during February and March in 2005 (3.8\%, 9.0\%, $37.2 \%, 50.0 \%)$ and during July and August in 2005 (2.7\%, $6.2 \%, 30.5 \%, 60.7 \%$ ) by Cozic et al. (2008), though in May
2008 the organic volume fraction was slightly lower and the $\mathrm{NH}_{4} \mathrm{NO}_{3}$ slightly higher. The time resolved volume fractions are fed into Eq. (4) to get the AMS/MAAP derived $\kappa$ as a function of time (Fig. 3d).

The relative contributions of $\mathrm{NH}_{4} \mathrm{NO}_{3}$ and $\left(\mathrm{NH}_{4}\right)_{2} \mathrm{SO}_{4}$ to the total inorganic volume fraction were changing significantly during the measurement period, whereas the inorganic to organic ratio exhibited much less variability. Since the $\kappa_{i}$ values of the different inorganic salts are similar, the overall $\kappa$ value does not experience large variations either (Fig. 3d). The campaign mean AMS/MAAP derived $\kappa$ value was 0.34 . This value is well representative for the global mean $\kappa$ values for continental regions $(0.27 \pm 0.21)$ whereas the mean value for marine regions $(0.72 \pm 0.24)$ is much higher (Andreae and Rosenfeld, 2008; Pringle et al., 2010).

\subsection{Applicability of using AMS bulk composition data}

Using bulk instead of size resolved chemical composition data does not introduce significant prediction bias for the following reasons:

1. The applicability of this simplification was confirmed by checking the size dependent AMS signal. 

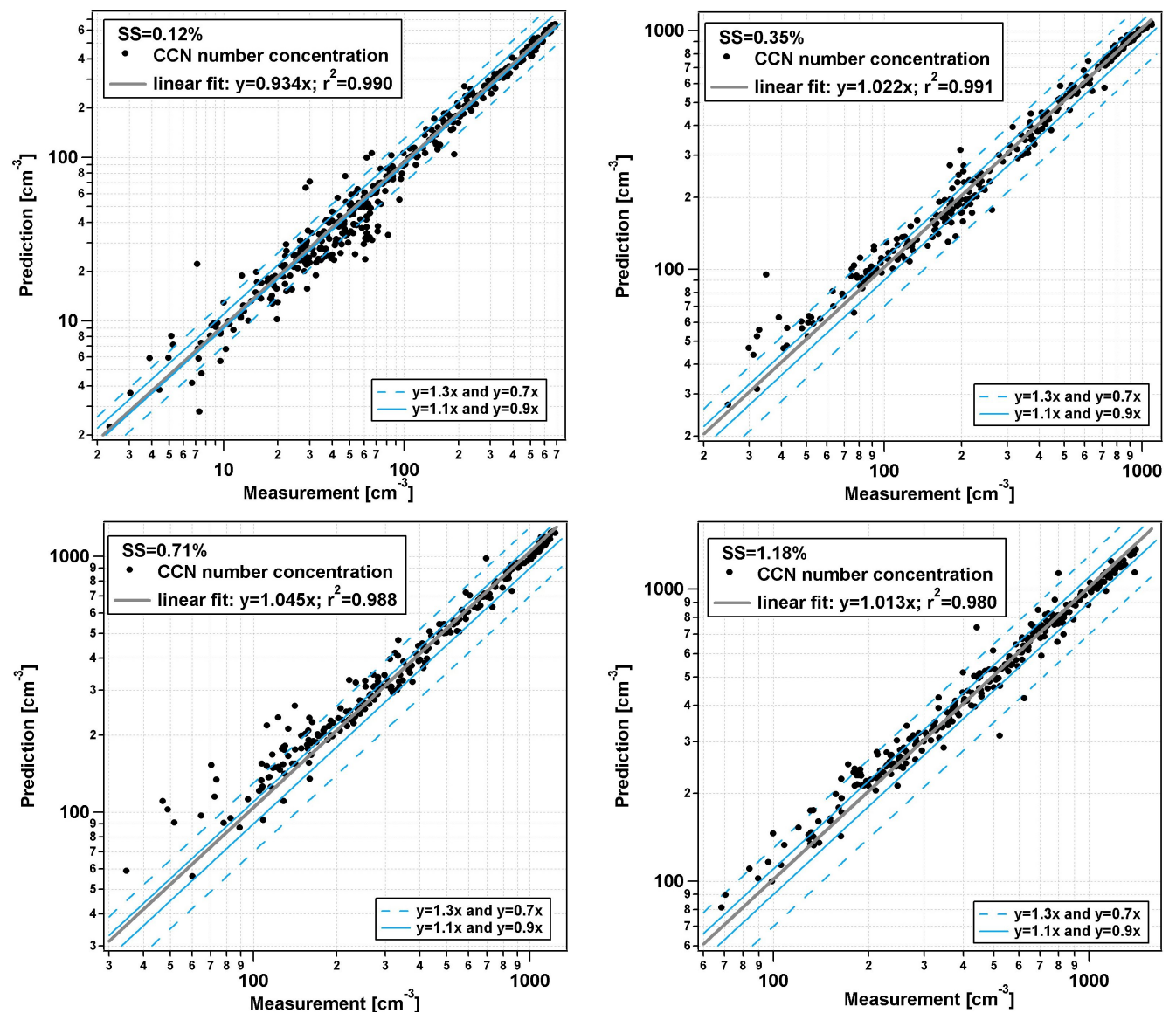

Fig. 4. Predicted vs. measured $\mathrm{CCN}$ number concentration for ambient aerosol at 4 different supersaturations using size distribution and chemical composition data. The grey line shows the fitted line through the data points. The method of the fit is explained in the text in details. The blue lines obey the $y=1.3 x, 1.1 x, 0.9 x, 0.7 x$ equations.

Throughout the diameter range of our interest only a very slight size dependence can be seen on average, and because of the very low mass concentrations at JFJ, the use of size dependent data would introduce much more noise than add true information on the size dependence of the composition.

2. The HTDMA measurements corroborate the fact that the $\kappa$ values show almost no size dependence at the Jungfraujoch (Kammermann et al., 2010b). The same measurements also showed that the aerosol is largely internally mixed with respect to hygroscopicity most of the time. Moreover, Ervens et al. (2010) also showed that assuming the two extreme cases - completely internally or externally mixed aerosols - does not result in a significant difference in the predicted $\mathrm{CCN}$ number concentration.

The chemical composition around $D_{0 \text {,crit }}(S S)$ is relevant for determining the $\mathrm{CCN}$ activation cut-off. The highest $D_{0, \text { crit }}$ values belong to the lowest supersaturations. The AMS integrates all the mass below $1.5 \mu \mathrm{m}$ in diameter (vac- uum aerodynamic diameter), therefore larger accumulation mode particles, carrying much more mass per particle, will mainly determine the measured chemical composition. For this reason, the measured chemical composition is biased towards larger diameters and with that it is most representative for low supersaturations. Fortunately $\mathrm{CCN}$ predictions are most sensitive to changes in the hygroscopicity parameter $\kappa$ at low supersaturations, while the susceptibility to $\kappa$ is small at medium and high supersaturations (see Sect. 4.6 for details).

\subsection{CCN prediction from chemical composition data}

Correlations between predicted and measured CCN number concentrations on log-log scale at 4 example supersaturations $(0.12 \%, 0.35 \%, 0.71 \%$ and $1.18 \%)$ are shown in Fig. 4. The solid and dashed blue lines represent agreement within $\pm 10 \%$ and $\pm 30 \%$, respectively. The orthogonal distance regression line weighted by inverse measurement uncertainties and forced through the origin is shown in grey. We associated $5 \%$ relative error to the measured and $10 \%$ to the predicted $\mathrm{CCN}$ number concentration. 
Table 3. Details on the predicted vs. measured CCN number concentration for the CCN prediction without simplifications. $a$ is the slope of the fitted line, $R^{2}$ is the square of the correlation coefficient.

\begin{tabular}{ccc}
\hline$S S[\%]$ & $a[-]$ & $R^{2}[-]$ \\
\hline 0.12 & 0.934 & 0.990 \\
0.24 & 1.028 & 0.992 \\
0.35 & 1.022 & 0.991 \\
0.47 & 1.042 & 0.987 \\
0.59 & 1.045 & 0.987 \\
0.71 & 1.045 & 0.988 \\
0.83 & 1.032 & 0.987 \\
0.95 & 1.049 & 0.979 \\
1.07 & 1.050 & 0.978 \\
1.18 & 1.013 & 0.980 \\
\hline
\end{tabular}

At every single $S S$ the slope of the fitted line is close to 1 which means that the CCN closure was successful (see Table 3 for results at all $S S$ ). On average $104 \%$ of the measured $\mathrm{CCN}$ concentration was predicted across all $S S$, with the highest value of $105.0 \%$ at $S S=1.07 \%$ and the lowest value of $93.4 \%$ at $S S=0.12 \%$. Overall, a very slight overprediction can be seen (except for the lowest $S S$ ), however, the deviations are clearly within the experimental uncertainty. At high $\mathrm{CCN}$ number concentrations most of the points are within the $10 \%$ and virtually all points within the $30 \%$ limits, while at lower number concentrations $\left(\# C C N<100-200 \mathrm{~cm}^{-3}\right.$, depending on which $S S$ one looks at) the scatter of individual data points increases slightly with a few of them exceeding the 30\% limit (see Fig. 5). The reason for this could be the overall increased uncertainty of the measurements closer to the detection limits of the instruments. Next to this most of the predictions outside the $30 \%$ limit belong to times when the mean diameter of the size distribution is very low (Fig. 5). This means that only the tail of the size distribution was integrated for the CCN prediction, where even a small absolute noise of the SMPS can cause relatively high prediction errors.

$\mathrm{CCN}$ predictions of our closure study agreed well with measured values for every single data point, which is reflected in a fitted slope of nearly unity as well as a high correlation coefficient $\left(R^{2}>0.97\right)$ between the two quantities. In a different CCN closure study Lance et al. (2009) reported agreement between prediction and measurement on average (fitted slope near unity), whereas the disagreement for individual data points was considerable (small correlation coefficient). The improved performance of our closure study is likely due to the fact that the number size distribution and chemical composition are more stable for the remote JFJ aerosol, which is not influenced by local pollution in contrast to measurements performed in the planetary boundary layer. Potential reasons for degrading performance of CCN closure studies conducted at sites closer to sources are: increased

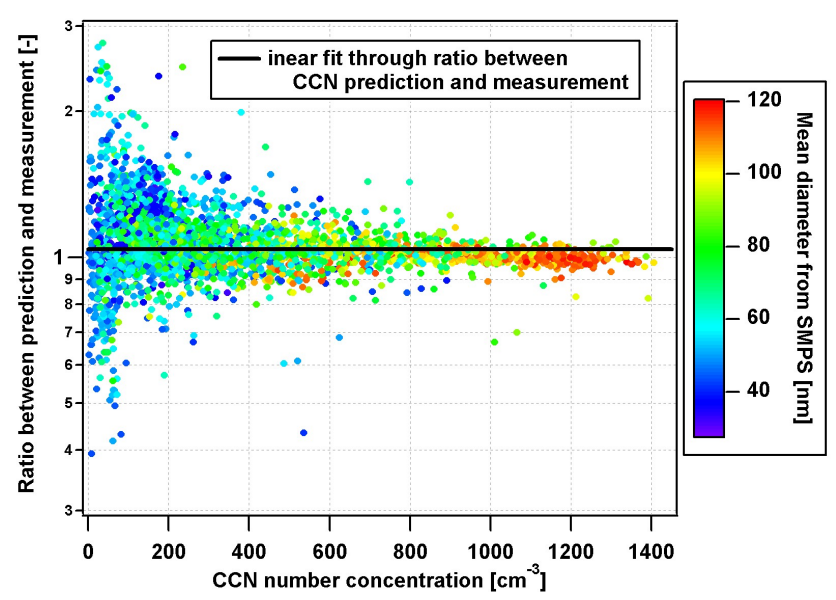

Fig. 5. The predicted-to-measured $\mathrm{CCN}$ number concentration at all $S S$ as function of the $\mathrm{CCN}$ number concentration coloured after the mean diameter of the number size distribution.

temporal variability of aerosol number concentration, shape of the number size distribution and chemical composition. In addition the assumption of size-independent chemical composition may become invalid (Ervens et al., 2010) and a substantial fraction of externally mixed particles with very low $\kappa$ values may be present.

\subsection{Performance of simplified $\mathrm{CCN}$ predictions}

The sensitivity of the CCN predictions to the input parameters was tested with different simplifying assumption regarding the number size distribution and chemical composition of the aerosol. The reference $\mathrm{CCN}$ prediction, considering all available measurements including their temporal variability, is shown as blue squares in Fig. 6. The green diamonds represent the $\mathrm{CCN}$ prediction assuming a constant chemical composition, i.e. mean $\kappa$ based on the average measured composition during the campaign $(\sim 0.34)$. Yellow triangles were calculated by ignoring the variability of the shape of the size distribution by time averaging the normalised SMPS scans. In this case the detailed chemical information was used, and the normalised average size distribution was scaled to the measured total particle number concentration $\left(N_{12-570}\right)$. Red points were derived by using the number size distribution averaged over the whole campaign in the model, so that the variability of the predicted points originates only from the changes in the chemical composition.

The simplified CCN predictions show that the CCN number concentrations are most sensitive to the temporal variability of the number size distribution (Fig. 6). Using the constant mean size distribution with considering the variability of chemical composition results in useless predictions (red points in Fig. 6). By contrast, deviations from the average measured chemical composition have little to no impact on the variability in the $\mathrm{CCN}$ number concentration (cf. blue 


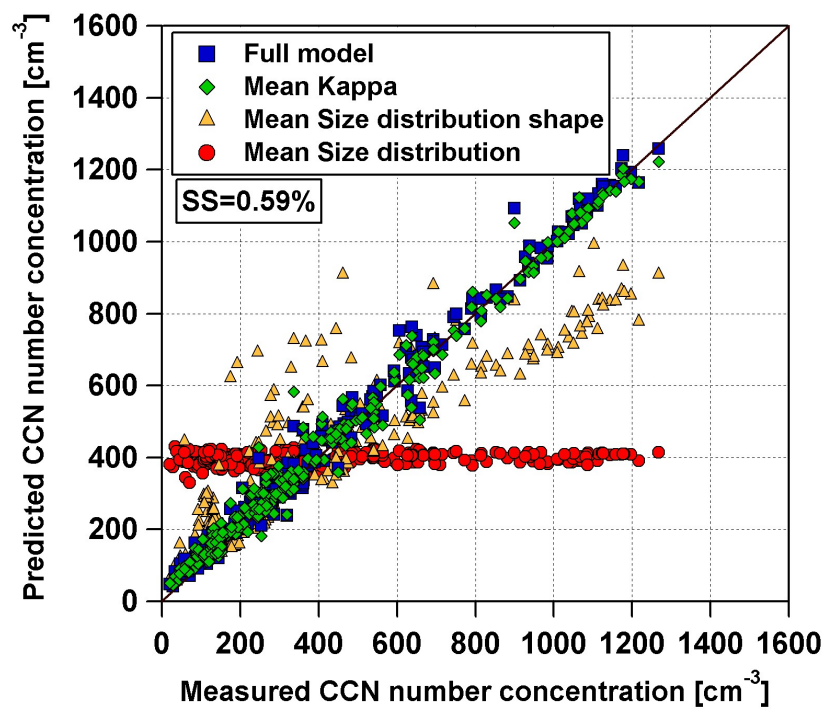

Fig. 6. Predicted vs. measured CCN number concentration for ambient aerosol at $S S=0.59 \%$ applying different simplifications in the calculation of the predicted CCN number concentration: full model (blue squares), time averaged $\kappa$ (green diamonds), time averaged size distribution shape (yellow triangles), time averaged number size distribution shape and concentration (red points). The thin black line represents the one-to-one ratio.

squares and green diamonds in Fig. 6). Neglecting only the temporal variability of the size distribution's shape yields still reasonable results (yellow triangles in Fig. 6), however, it has much bigger influence on the prediction's performance than the temporal variability of the chemical composition. Thus, for an aerosol with a relatively constant chemical composition such as at the Jungfraujoch size indeed matters more than chemistry (Dusek et al., 2006), however, this does not necessarily hold for other aerosol types and supersaturations.

The volume fraction of the inorganic compounds ranged from $20 \%$ to $80 \%$ with the 10 th percentile of $37 \%$, median of $45 \%$ and 90 th percentile of $66 \%$ during the one-month observation period. Even though substantial variations in chemical composition were observed, significant differences between the reference prediction and the time averaged $\kappa$ case cannot be seen. The model performance gets only slightly worse (larger $\chi^{2}$ values at most of the SS, not shown here) if the time variance of the chemical composition is ignored. Based on this analysis, the temporal variability of the chemical information could be skipped for the calculation, still yielding a reliable $\mathrm{CCN}$ prediction at the JFJ.

\subsection{Susceptibility to surface tension}

Several laboratory studies on organic aerosols indicate that surface tension suppression effects may occur (e.g. Shilling et al., 2007; King et al., 2009). In contrast the results of our closure study give no indication for a suppressed surface ten- sion of the aerosol at the point of CCN activation. Aerosols with suppressed surface tension activate at lower $S S_{\text {crit }}$ because the Kelvin effect term in Eq. (1) is decreased. Assuming a $10 \%$ reduction of surface tension at the point of $\mathrm{CCN}$ activation relative to pure water increases the predicted $\mathrm{CCN}$ number concentration. Consequently the overprediction becomes even higher and reaches a factor of 1.12 averaged over the whole data set compared to a factor of 1.04 with assuming surface tension of pure water. Kammermann et al. (2010a) compiled an overview of the performance of existing hygroscopicity-CCN closure studies, revealing that the CCN number concentration was underpredicted in only 1 out of 10 cases, always assuming surface tension of pure water. This is in line with our result that assuming reduced surface tension impairs the performance of $\mathrm{CCN}$ predictions. However, Good et al. (2010a) also reported underprediction of $\mathrm{CCN}$ number concentration, which might be an indication for suppressed surface tension in their case.

One has to note that closure with assuming surface tension of pure water might be untruly achieved by compensating errors if both hygroscopicity parameter $\kappa$ and surface tension are in reality smaller than the values used in the calculations (see also Sect. 4.7). Furthermore, it is also not possible to distinguish between a true absence of surface tension depression and the presence of surface active species compensated by bulk/surface partitioning effects (Sorjamaa et al., 2004) such that one can still assume surface tension of pure water at the point of $\mathrm{CCN}$ activation.

\subsection{Susceptibility to chemical composition}

The susceptibility of CCN predictions to the absolute value and the variability of the chemical composition $(\kappa)$ was further investigated by a detailed sensitivity analysis. For each $S S$ and each time the relative change in the predicted $\mathrm{CCN}$ number concentration at varying $\kappa$ parameter $(0<\kappa<0.8)$ was calculated with the help of the measured size distribution. Figure 7 shows one example of the susceptibility to $\kappa$ for a medium $S S$ of $0.59 \%$. The colour scale indicates relative $\mathrm{CCN}$ prediction errors (hereafter referred to as CCNerror) if the $\kappa$ value shown on the ordinate is used for the prediction instead of the AMS derived $\kappa$ (grey points). The CCNerror is by definition zero at the grey points. The black lines indicate the lower and upper limits of acceptable $\kappa$ values for which CCNerror $<10 \%$. The sensitivity of CCN number concentrations is strongly time dependent, reflected in the variability of the equipotential lines of $\mathrm{CCN}$ error (see black lines as example). This is mainly caused by the variability of the shape of the size distribution. Nevertheless, a common feature is that $\mathrm{CCN}$ number concentrations are generally much more sensitive to a decrease than to an increase in $\kappa$, which originates from the nonlinear dependence of $D_{0 \text {, crit }}$ on $\kappa$.

The mean susceptibility of CCN predictions to the variability of the chemical composition $(\kappa)$ for all $S S$ is shown in Fig. 8. Note that temporal averaging over the whole 


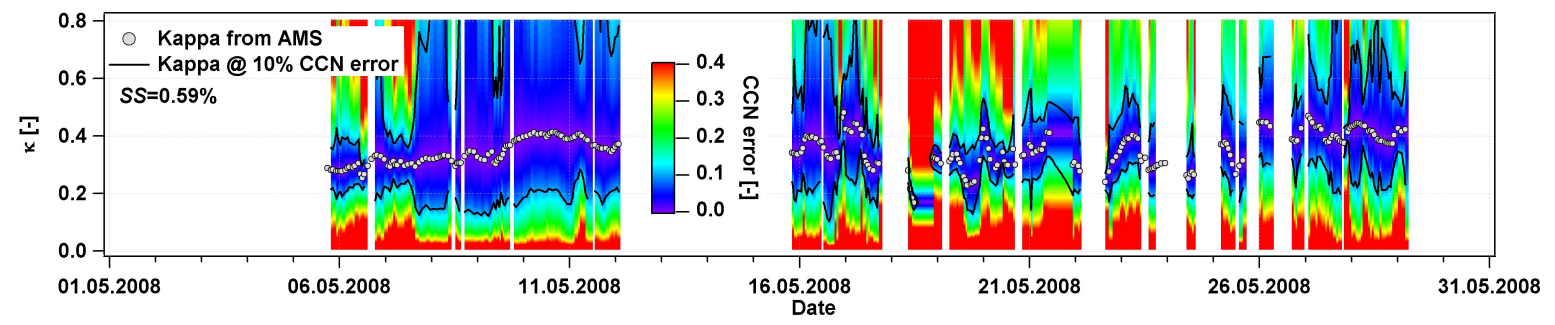

Fig. 7. Sensitivity of the prediction to the $\kappa$ at $0.59 \%$ SS as a function of time. The grey dots show the AMS derived $\kappa$ parameter. The different colours represent the relative change of the predicted CCN concentration as a function of the chosen $\kappa$.

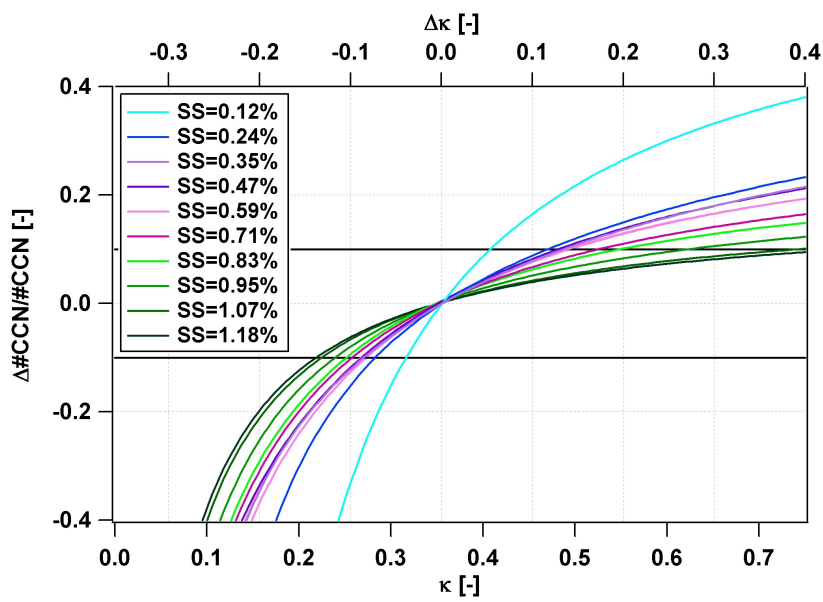

Fig. 8. Time-averaged sensitivity of $\mathrm{CCN}$ prediction to changes in assumed $\kappa$ value. The different colours indicate the different supersaturations.

measurement campaign of the relative prediction error was done against $\Delta \kappa$, and then the $\Delta \kappa$ scale was converted back to absolute $\kappa$ values using the campaign mean $\kappa$ of $\sim 0.34$. $\mathrm{CCN}$ number concentrations at the lowest investigated $S S$ $(0.12 \%)$ are much more sensitive to the chemical composition change than at any higher $S S$. At this lowest $S S \kappa$ can only vary by $-11 \%$ to $+15 \%$ to stay within $10 \%$ in the calculated CCN number concentration. The corresponding tolerance for $\kappa$ at the second lowest $S S(0.24 \%)$ is already $-20 \%$ to $+32 \%$, increasing up to $-37 \%$ to $+120 \%$ at the highest SS $(1.18 \%)$. A priori one would expect a symmetrically mirrored order of the sensitivity curves at different $S S$ for positive and negative $\Delta \kappa$, i.e. the curves shown in Fig. 9 are expected to cross each other at $\Delta \kappa=0$ and nowhere else. This is the case for most pairs of sensitivity curves. However, the sensitivity to $\kappa$ for nearby supersaturations (e.g. $S S=0.59 \%$ and $S S=0.47 \%$ ) is very similar such that experimental uncertainties can explain deviations from the expected symmetry, always bearing in mind that these sensitivity curves are based on experimental size distribution and $\mathrm{CCN}$ data acquired at slightly different times for different $S S$.
From this sensitivity analysis we can conclude that a change in the chemical composition has only a small influence on the predicted CCN number concentrations except for very low SS. Since the campaign mean $\kappa$ value (0.34) is representative of continental sites around the globe (Andreae and Rosenfeld, 2008; Pringle et al., 2010), a similarly weak sensitivity of CCN number concentrations to chemical composition can also be expected for other continental sites. Even smaller sensitivity to chemical composition is expected for marine regions where the mean $\kappa$ is higher $(0.72 \pm 0.24$; Andreae and Rosenfeld, 2008; Pringle et al., 2010). However, it is important to note that this might not be true for places, where the aerosol is much less hygroscopic with lower $\kappa$ values as for example reported in rainforests (Gunthe et al., 2009) or occasionally also at a site in Northern Europe (Kammermann et al., 2010a).

\subsection{Using HTDMA data for $\mathrm{CCN}$ prediction}

Here we show that HTDMA data can also be used to determine the hygroscopicity parameter $\kappa$ required for the $\mathrm{CCN}$ prediction instead of the chemical composition data. In this case information on the mixing state of the aerosol with respect to hygroscopic properties is also known (Kammermann et al., 2010a), and the Köhler curve can be extrapolated from below saturation to the supersaturated region using the $\kappa$ parameterisation. A comparison of the $\kappa$ parameters derived from the different instruments is shown in Fig. 9. Since the $\mathrm{CCN}$ number concentration is relatively insensitive to the changes in the $\kappa$ parameter, the $\mathrm{CCNC}$ derived $\kappa$ values are very noisy, and therefore 5 -h running mean values are presented for all instruments. The $D_{0}=50 \mathrm{~nm}$ HTDMA measurements are most suitable for comparison with the CCN measurements at $S S=0.59 \%$, because the average $D_{0, \text { crit }}$ at this $S S$, inferred from number size distribution and $C C N$ number concentration data, is $\sim 56 \mathrm{~nm}$. Even if there is sometimes a significant difference between the CCNC (brown dotted line) and the AMS/MAAP (black line) derived $\kappa$ values, the closure comparing the measured and calculated CCN number concentration worked almost perfectly. This is because the calculated CCN number concentration is relatively insensitive to the changes in the chemical composition $(\kappa$ value) as it was shown in Sect. 4.6. 


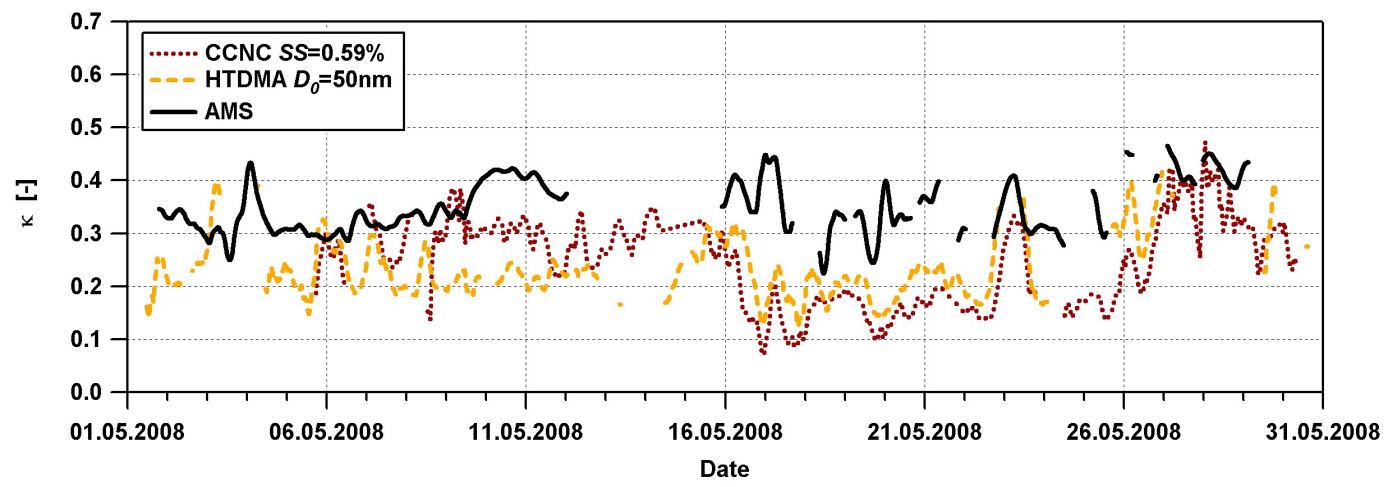

Fig. 9. Time series of hygroscopicity parameter $\kappa$ derived from the different instruments.

HTDMA and CCNC derived $\kappa$ values correlate well at most times and their overall agreement is better than the agreement between AMS/MAAP and CCNC derived $\kappa$ values. Therefore even better agreement between $\mathrm{CCN}$ measurement and prediction is obtained if the size distribution data are combined with the HTDMA derived hygroscopicity parameter for the $\mathrm{CCN}$ prediction (not shown).

$\mathrm{CCN}$ predictions are complicated by several factors including the potential occurrence of surface tension suppression, bulk to surface partitioning effects of surface active species, or strong dependence of the water activity coefficient on the concentration of the solution droplet. Good et al. (2010b) reported that experimental differences between HTDMA instruments operated in parallel made it impossible to determine whether or not the above effects occur. Furthermore, $\mathrm{CCN}$ properties predicted from the hygroscopic growth measured at subsaturated RH were substantially different when using data from different HTDMA instruments. What does this mean for the interpretation of our closure results? Good et al. (2010b) investigated pure organic and organic dominated aerosols (organic fraction $>80 \%$ for the most part) produced in a smogchamber by photo-oxidation of $\alpha$-pinene. Duplissy et al. (2009) reported for this particular aerosol type discrepancies between different HTDMA instruments that compared well for inorganic aerosol during the same intercomparison study. Whether or not such discrepancies between different HTDMA instruments also occur for ambient aerosols has not yet been shown to our knowledge. The organic aerosol investigated by Good et al. (2010b) has a rather low hygroscopicity $(\kappa \sim 0.1-0.15)$, which makes predicted $\mathrm{CCN}$ properties much more sensitive to experimental uncertainties (see Fig. 8), compared to the aerosol at the Jungfraujoch. Furthermore, the study by Good et al. (2010b) compares the properties of $\mathrm{CCN}$ rather than $\mathrm{CCN}$ number concentration. Comparison of $\mathrm{CCN}$ properties emphasizes small discrepancies, whereas $\mathrm{CCN}$ number concentrations of a polydisperse aerosol are much less sensitive to uncertainties in $\kappa$. This fact is illustrated by Figs. 4, 8 and 9 of this study: substantial differences in $\kappa$ translate only into small differences of corresponding CCN number concentrations. As a consequence it is not possible to attribute the differences in $\kappa$ values reported here (Fig. 9) to experimental uncertainties or one of the above-mentioned effects with certainty, but we can constrain the hygroscopicity parameter $\kappa$ from either AMS/MAAP or HTDMA measurements well enough to predict the $\mathrm{CCN}$ number concentration within a few percent.

\subsection{Influence of Saharan dust events on the $\mathrm{CCN}$ number concentration}

During SDE periods at the JFJ significant mass of mineral dust, predominately located in the coarse mode, might be present. Therefore it is in principle possible that the bulk chemical composition changes to that extent that our $\mathrm{CCN}$ predictions, which ignore mineral dust in the composition, become significantly biased. Through the one-month measurement campaign we detected only one SDE according to the criterion by Collaud Coen et al. (2004). The event was strong and lasted almost 3 days (26 May 2009 12:00-29 May 2009 12:00, CET $=\mathrm{UTC}+1$ ). Based on previous HTDMA measurements at this site (Sjogren et al., 2008) we can state that a substantial fraction of externally mixed SDE particles can occasionally be found at $D=250 \mathrm{~nm}$ in extreme cases, though a more comprehensive data set shows that the overall contribution of mineral dust at sizes with $D<265 \mathrm{~nm}$ remains negligible even during strong SDE (Kammermann et al., 2010b). Here we tested the hypothesis whether neglecting mineral dust in the composition impairs our CCN prediction during the SDE or not. Therefore we split the measurement data into non-SDE and SDE periods according to the criterion by Collaud Coen et al. (2004) and compared the prediction performance between these two cases (Fig. 10). Both fitted slopes (orthogonal regression with weighting as previously explained) of 1.04 and 1.05 as well as correlation coefficients $R^{2}=0.99$ and 0.96 are equal within uncertainty for the non-SDE and SDE periods, respectively. 


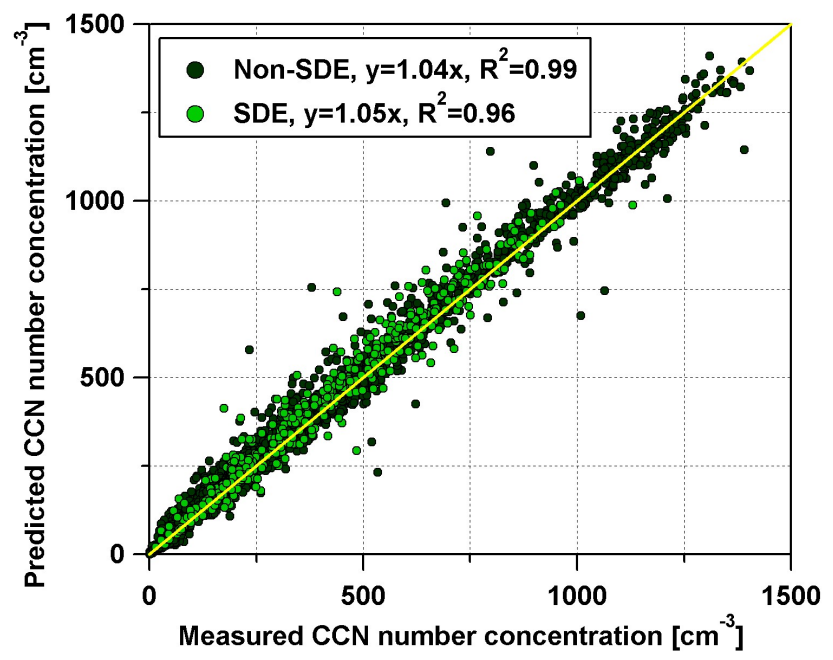

Fig. 10. Predicted vs. measured $\mathrm{CCN}$ number concentration during non-SDE period (dark green) and the SDE period (light green). All supersaturations are included. The yellow line represents the oneto-one ratio.

This shows that ignoring the mineral dust component in the chemical composition does not impair $\mathrm{CCN}$ prediction. On the contrary, using bulk composition including mineral dust would bias CCN predictions, because coarse mode mineral dust gives a major contribution to total mass (Cozic et al., 2008), whereas the contribution of mineral dust to particle number concentration at those Aitken and accumulation mode sizes in the CCN cut-off range is negligible.

\section{Conclusions}

The CCN number concentration observed at the Jungfraujoch was predicted reliably from measured aerosol number size distribution and chemical composition data using a simplified parameterisation of the Köhler theory. Both, average values and temporal variability of $\mathrm{CCN}$ number concentration were well predicted across the whole SS range. Significant underprediction was not experienced, indicating that one can assume surface tension of pure water. A comparison of HTDMA, AMS/MAAP and CCNC derived $\kappa$ values showed that HTDMA measurements can be used to determine particle hygrscopicity required for $\mathrm{CCN}$ predictions if no suitable chemical composition measurement is available.

The composition derived campaign mean $\kappa$ value was found to be $\sim 0.34$. A detailed sensitivity analysis showed that this $\kappa$ value is in a range, where a variation in the $\kappa$ value around its mean value has only a small influence on the resulting $\mathrm{CCN}$ number concentration. Therefore it can be expected that the CCN number concentration at the Jungfraujoch site can generally be well predicted from size distribution data with assuming a surface tension of pure water and a constant hygroscopicity parameter of $\sim 0.34$, though our

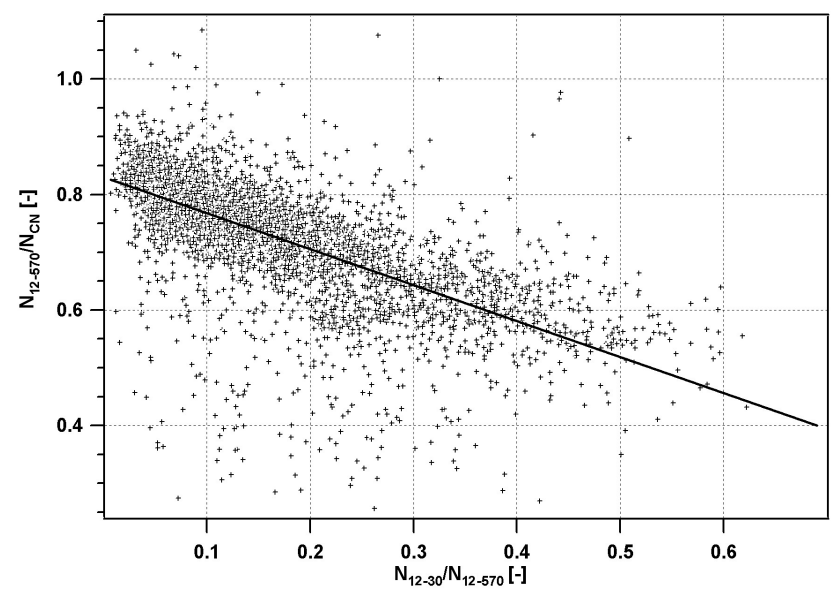

Fig. A1. The ratio between the integrated SMPS concentration $\left(N_{12-570}\right)$ and the total concentration $\left(N_{\mathrm{CN}}\right)$ as a function of the fraction of small particles. The black line represents the linear fit through the data points.

long-term measurements might provide a statistically more representative value for the mean $\kappa$ value. A continuous 17months dataset with $\mathrm{CCN}$ number concentration and size distribution measurements will make us also able to investigate the influence of seasonal and short-term variations of the size distribution on the CCN activation at JFJ in more detail.

\section{Appendix A}

The total number concentration of particles with diameter larger than $10 \mathrm{~nm}\left(N_{\mathrm{CN}}\right)$ measured by the CPC was compared to the integrated SMPS number concentration $\left(N_{12-570}\right)$ in order to validate the SMPS measurement. The measured total number concentration is expected to be higher than $N_{12-570}$ always if nucleation mode particles with sizes $D \approx 10 \mathrm{~nm}$ are present because the CPC has a lower cut-off than the SMPS. $N_{12-570}$ and $\left(N_{\mathrm{CN}}\right)$ are only expected to agree if no nucleation mode particles nor a substantial number fraction of particles with $D>570 \mathrm{~nm}$ are present. In this case any disagreement between $N_{12-570}$ and $N_{\mathrm{CN}}$ is related to instrumen$\mathrm{tal} /$ measurement errors and can be used for a correction.

In Sect. 4.1 we have seen that the number concentration above $570 \mathrm{~nm}$ was negligible during the whole campaign, therefore we only have to exclude periods with nucleation mode particles for the comparison. In order to do so the number fraction of small particles (integrated SMPS number concentration between $D=12$ and $30 \mathrm{~nm}, N_{12-30}$ ) relative to total $N_{12-570}$ was calculated as an indicator for the presence of the small particles. Then the ratio of $N_{12-570}$ to $\left(N_{\mathrm{CN}}\right)$ was plotted against the proxy of the small particles (Fig. A1). As expected the ratio $\left(N_{12-570} / N_{\mathrm{CN}}\right)$ decreases with increasing number fraction of small particles. However, the intercept between fitted line and ordinate, i.e. the 
ratio $\left(N_{12-570} / N_{\mathrm{CN}}\right)$ in the absence of small particles is at 0.83 instead of unity, indicating that the SMPS was undercounting by $\sim 17 \%$. Undercounting of the SMPS may have been caused by slight deviations of the sample and sheath flow rates from the nominal values, or a DMA transfer probability which was lower than assumed. Therefore the number concentration measured by the SMPS was corrected by a size-independent factor $1 / 0.83 \approx 1.20$. The necessity and the absolute value of the correction factor to be applied to the SMPS data were confirmed by comparison of the measured and calculated aerosol scattering coefficient (Mie calculations using SMPS data compared to the nephelometer measurement; Fierz-Schmidhauser et al., 2010).

Acknowledgements. We would like to thank Andreas Petzold for lending his MAAP instrument to us. We thank the International Foundation High Altitude Research Stations Jungfraujoch and Gornergrat (HFSJG) for the opportunity to perform experiments on the Jungfraujoch. Financial support from MeteoSwiss in the framework of the Global Atmosphere Watch program, from the Swiss National Science Foundation and from the EU FP6 projects EUCAARI and EUSAAR is gratefully acknowledged. P. F. DeCarlo is grateful for support from the US-NSF (IRFP \#0701013).

Edited by: A. Wiedensohler

\section{References}

Albrecht, B. A.: Aerosols, cloud microphysics, and fractional cloudiness, Science, 245, 1227-1230, 1989.

Andreae, M. O. and Rosenfeld, D.: Aerosol-cloudprecipitation interactions. Part 1. The nature and sources of cloud-active aerosols, Earth. Sci. Rev., 89(1-2), 13-41, doi:10.1016/j.earscirev.2008.03.001, 2008.

Baltensperger, U., Gäggeler, H. W., Jost, D. T., Lugauer, M., Schwikowski, M., Weingartner, E., and Seibert, P.: Aerosol climatology at the high-alpine site Jungfraujoch, Switzerland, J. Geophys. Res., 102, 19707-19715, 1997.

Bougiatioti, A., Fountoukis, C., Kalivitis, N., Pandis, S. N., Nenes, A., and Mihalopoulos, N.: Cloud condensation nuclei measurements in the marine boundary layer of the Eastern Mediterranean: CCN closure and droplet growth kinetics, Atmos. Chem. Phys., 9, 7053-7066, doi:10.5194/acp-9-7053-2009, 2009.

Broekhuizen, K., Chang, R. Y.-W., Leaitch, W. R., Li, S.-M., and Abbatt, J. P. D.: Closure between measured and modeled cloud condensation nuclei $(\mathrm{CCN})$ using size-resolved aerosol compositions in downtown Toronto, Atmos. Chem. Phys., 6, 2513-2524, doi:10.5194/acp-6-2513-2006, 2006.

Canagaratna, M. R., Jayne, J. T., Jimenez, J. L., Allan, J. D., Alfarra, M. R., Zhang, Q., Onasch, T. B., Drewnick, F., Coe, H., Middlebrook, A., Delia, A., Williams, L. R., Trimborn, A. M., Northway, M. J., DeCarlo, P. F., Kolb, C. E., Davidovits, P., and Worsnop, D. R.: Chemical and microphysical characterization of ambient aerosols with the aerodyne aerosol mass spectrometer, Mass Spec. Rev., 26, 185-222, 2007.

Clegg, S. L., Brimblecombe, P., and Wexler, A. S.: Thermodynamic model of the system
$\mathrm{H}^{+}-\mathrm{NH}_{4}^{+}-\mathrm{Na}^{+}-\mathrm{SO}_{4}^{2-}-\mathrm{NO}_{3}^{-}-\mathrm{Cl}^{-}-\mathrm{H}_{2} \mathrm{O}$ at $298.15 \mathrm{~K}$, J. Phys. Chem., A102, 2155-2171, 1998.

Collaud Coen, M., Weingartner, E., Nyeki, S., Cozic, J., Henning, S., Verheggen, B., Gehrig, R., and Baltensperger, U.: Long-term trend analysis of aerosol variables at the highalpine site Jungfraujoch, J. Geophys. Res., 112, D13213, doi:10.1029/2006JD007995, 2007.

Collaud Coen, M., Weingartner, E., Schaub, D., Hueglin, C., Corrigan, C., Henning, S., Schwikowski, M., and Baltensperger, U.: Saharan dust events at the Jungfraujoch: detection by wavelength dependence of the single scattering albedo and first climatology analysis, Atmos. Chem. Phys., 4, 2465-2480, doi:10.5194/acp4-2465-2004, 2004.

Cozic, J., Verheggen, B., Weingartner, E., Crosier, J., Bower, K. N., Flynn, M., Coe, H., Henning, S., Steinbacher, M., Henne, S., Collaud Coen, M., Petzold, A., and Baltensperger, U.: Chemical composition of free tropospheric aerosol for PM1 and coarse mode at the high alpine site Jungfraujoch, Atmos. Chem. Phys., 8, 407-423, doi:10.5194/acp-8-407-2008, 2008.

Cross, E. S., Slowik, J. G., Davidovits, P., Allan, J. D., Worsnop, D. R., Jayne, J. T., Lewis, D. K., Canagaratna, M., and Onasch, T. B.: Laboratory and ambient particle density determinations using light scattering in conjunction with aerosol mass spectrometry, Aerosol Sci. Technol., 41, 343-359, 2007.

Cubison, M. J., Ervens, B., Feingold, G., Docherty, K. S., Ulbrich, I. M., Shields, L., Prather, K., Hering, S., and Jimenez, J. L.: The influence of chemical composition and mixing state of Los Angeles urban aerosol on CCN number and cloud properties, Atmos. Chem. Phys., 8, 5649-5667, doi:10.5194/acp-8-5649-2008, 2008.

DeCarlo, P. F., Kimmel, J. R., Trimborn, A., Northway, M. J., Jayne, J. T., Aiken, A. C., Gonin, M., Fuhrer, K., Horvath, T., Docherty, K. S., Worsnop, D. R., and Jimenez, J. L.: Field-deployable, high-resolution, time-of-flight aerosol mass spectrometer, Anal. Chem., 78, 8281-8289, 2006.

Duplissy, J., Gysel, M., Sjogren, S., Meyer, N., Good, N., Kammermann, L., Michaud, V., Weigel, R., Martins dos Santos, S., Gruening, C., Villani, P., Laj, P., Sellegri, K., Metzger, A., McFiggans, G. B., Wehrle, G., Richter, R., Dommen, J., Ristovski, Z., Baltensperger, U., and Weingartner, E.: Intercomparison study of six HTDMAs: results and recommendations, Atmos. Meas. Tech., 2, 363-378, doi:10.5194/amt-2-363-2009, 2009.

Dusek, U., Frank, G. P., Hildebrandt, L., Curtius, J., Schneider, J., Walter, S., Chand, D., Drewnick, F., Hings, S., Jung, D., Borrmann, S., and Andreae, M. O.: Size matters more than chemistry for cloud-nucleating ability of aerosol particles, Science, 312, 1375-1378, 2006.

Ervens, B., Cubison, M., Andrews, E., Feingold, G., Ogren, J. A., Jimenez, J. L., DeCarlo, P., and Nenes, A.: Prediction of cloud condensation nucleus number concentration using measurements of aerosol size distributions and composition and light scattering enhancement due to humidity. J. Geophys. Res., 112, D10S32, doi:10.1029/2006JD007426, 2007.

Ervens, B., Cubison, M. J., Andrews, E., Feingold, G., Ogren, J. A., Jimenez, J. L., Quinn, P. K., Bates, T. S., Wang, J., Zhang, Q., Coe, H., Flynn, M., and Allan, J. D.: CCN predictions using simplified assumptions of organic aerosol composition and mixing state: a synthesis from six different locations, Atmos. Chem. Phys., 10, 4795-4807, doi:10.5194/acp-10-4795-2010, 2010. 
Fierz-Schmidhauser, R., Zieger, P., Gysel, M., Kammermann, L., DeCarlo, P. F., Baltensperger, U., and Weingartner, E.: Measured and predicted aerosol light scattering enhancement factors at the high alpine site Jungfraujoch, Atmos. Chem. Phys., 10, 23192333, doi:10.5194/acp-10-2319-2010, 2010.

Good, N., Topping, D. O., Allan, J. D., Flynn, M., Fuentes, E., Irwin, M., Williams, P. I., Coe, H., and McFiggans, G.: Consistency between parameterisations of aerosol hygroscopicity and CCN activity during the RHaMBLe discovery cruise, Atmos. Chem. Phys., 10, 3189-3203, doi:10.5194/acp-10-3189-2010, 2010a.

Good, N., Topping, D. O., Duplissy, J., Gysel, M., Meyer, N. K., Metzger, A., Turner, S. F., Baltensperger, U., Ristovski, Z., Weingartner, E., Coe, H., and McFiggans, G.: Widening the gap between measurement and modelling of secondary organic aerosol properties?, Atmos. Chem. Phys., 10, 2577-2593, doi:10.5194/acp-10-2577-2010, 2010 b.

Gunthe, S. S., King, S. M., Rose, D., Chen, Q., Roldin, P., Farmer, D. K., Jimenez, J. L., Artaxo, P., Andreae, M. O., Martin, S. T., and Pöschl, U.: Cloud condensation nuclei in pristine tropical rainforest air of Amazonia: size-resolved measurements and modeling of atmospheric aerosol composition and CCN activity, Atmos. Chem. Phys., 9, 7551-7575, doi:10.5194/acp-9-75512009, 2009.

Gysel, M., McFiggans, G. B., and Coe, H.: Inversion of tandem differential mobility analyser (TDMA) measurements, J. Aerosol Sci., 40, 134-151, 2009.

Henning, S., Weingartner, E., Schmidt, S., Wendisch, M., Gäggeler, H. W., and Baltensperger, U.: Size-dependent aerosol activation at the high-alpine site Jungfraujoch (3580 m asl), Tellus, 54B, 82-95, 2002.

Henning, S., Weingartner, E., Schwikowski, M., Gäggeler, H. W., Gehrig, R., Hinz, K. P., Trimborn, A., Spengler, B., and Baltensperger, U.: Seasonal variation of water-soluble ions of the aerosol at the high-alpine site Jungfraujoch (3580 ma.s.1.), J. Geophys. Res., 108, 4030, doi:10.1029/2002JD002439, 2003.

Herich, H., Tritscher, T., Wiacek, A., Gysel, M., Weingartner, E., Lohmann, U., Baltensperger, U., and Cziczo, D. J.: Water uptake of clay and desert dust aerosol particles at sub- and supersaturated water vapor conditions, Phys. Chem. Chem. Phys., 11, 7804-7809, 2009.

IPCC, Solomon, S., Qin, D., Manning, M., Marquis, M., Averyt, K., Tignor, M. M. B., Miller, H. L. J., and Chen, Z. (eds.): Climate Change 2007 - The Physical Science Basis. Contribution of Working Group I to the Fourth Assessment Report of the Intergovernmental Panel on Climate Change, Cambridge University Press, Cambridge, 153-154 and 171-172, 2007.

Jurányi, Z., Gysel, M., Duplissy, J., Weingartner, E., Tritscher, T., Dommen, J., Henning, S., Ziese, M., Kiselev, A., Stratmann, F., George, I., and Baltensperger, U.: Influence of gasto-particle partitioning on the hygroscopic and droplet activation behaviour of $\alpha$-pinene secondary organic aerosol, Phys. Chem. Chem. Phys., 11, 8091-8097, 2009.

Kammermann, L., Gysel, M., Weingartner, E., Herich, H., Cziczo, D. J., Holst, T., Svenningsson, B., Arneth, A., and Baltensperger, U.: Subarctic atmospheric aerosol composition: 3. Measured and modeled properties of cloud condensation nuclei, J. Geophys. Res., 115, D04202, doi:10.1029/2009JD012447, 2010a.

Kammermann, L., Gysel, M., Weingartner, E., and Baltensperger,
U.: 13-month climatology of the aerosol hygroscopicity at the free tropospheric site Jungfraujoch (3580 m a.s.1.), Atmos. Chem. Phys. Discuss., 10, 13573-13608, doi:10.5194/acpd-1013573-2010, 2010b.

Keith, C. H. and Arons, A. B.: The growth of sea-salt particles by condensation of atmospheric water vapor. J. Meteorol., 11, 173184, 1954.

King, S. M., Rosenoern, T., Shilling, J. E., Chen, Q., and Martin, S. T.: Increased cloud activation potential of secondary organic aerosol for atmospheric mass loadings, Atmos. Chem. Phys., 9, 2959-2971, doi:10.5194/acp-9-2959-2009, 2009.

Koehler, K. A., Kreidenweis, S. M., DeMott, P. J., Petters, M. D., Prenni, A. J., and Carrico, C. M.: Hygroscopicity and cloud droplet activation of mineral dust aerosol. Geophys. Res. Lett., 36, L08805, doi:10.1029/2009GL037348, 2009.

Köhler, H.: The nucleus in and the growth of hygroscopic droplets. Trans. Faraday Soc., 32, 1152-1161, 1936.

Krivácsy, Z., Hoffer, A., Sárvári, Z., Temesi, D., Baltensperger, U., Nyeki, S., Weingartner, E., Kleefeld, S., and Jennings, S. G.: Role of organic and black carbon in the chemical composition of atmospheric aerosol at European background sites, Atmos. Environ., 35, 6231-6244, 2001.

Kulmala, M., Asmi, A., Lappalainen, H. K., Carslaw, K. S., Pöschl, U., Baltensperger, U., Hov, Ø., Brenquier, J.-L., Pandis, S. N., Facchini, M. C., Hansson, H.-C., Wiedensohler, A., and O'Dowd, C. D.: Introduction: European Integrated Project on Aerosol Cloud Climate and Air Quality interactions (EUCAARI) - integrating aerosol research from nano to global scales, Atmos. Chem. Phys., 9, 2825-2841, doi:10.5194/acp-9-2825-2009, 2009.

Kuwata, M., Kondo, Y., and Takegawa, N.: Critical condensed mass for activation of black carbon as cloud condensation nuclei in Tokyo, J. Geophys. Res., 114, D20202, doi:10.1029/2009JD012086, 2009.

Lance, S., Nenes, A., Mazzoleni, C., Dubey, M. K., Gates, H., Varutbangkul, V., Rissman, T. A., Murphy, S. M., Sorooshian, A., Flagan, R. C., Seinfeld, J. H., Feingold, G., and Jonsson, H. H.: Cloud condensation nuclei activity, closure, and droplet growth kinetics of Houston aerosol during the Gulf of Mexico Atmospheric Composition and Climate Study (GoMACCS), J. Geophys. Res., 114, D00F15, doi:10.1029/2008JD011699, 2009.

Liu, P. S. K., Leaitch, W. R., Banic, C. M., Li, S. M., Ngo, D., and Megaw, W. J.: Aerosol observations at Chebogue Point during the 1993 North Atlantic Regional Experiment: Relationships among cloud condensation nuclei, size distribution, and chemistry, J. Geophys. Res., 101, 28971-28990, 1996.

McFiggans, G., Artaxo, P., Baltensperger, U., Coe, H., Facchini, M. C., Feingold, G., Fuzzi, S., Gysel, M., Laaksonen, A., Lohmann, U., Mentel, T. F., Murphy, D. M., O’Dowd, C. D., Snider, J. R., and Weingartner, E.: The effect of physical and chemical aerosol properties on warm cloud droplet activation, Atmos. Chem. Phys., 6, 2593-2649, doi:10.5194/acp-6-2593-2006, 2006.

Moore, R. H., Ingall, E. D., Sorooshian, A., and Nenes, A.: Molar mass, surface tension, and droplet growth kinetics of marine organics from measurements of CCN activity, Geophys. Res. Lett., 35, L07801, doi:10.1029/2008GL033350, 2008.

Nyeki, S., Baltensperger, U., Colbeck, I., Jost, D. T., Weingart- 
ner, E., and Gäggeler, H. W.: The Jungfraujoch high-Alpine research station (3454 $\mathrm{m}$ ) as a background clean continental site for the measurement of aerosol parameters, J. Geophys. Res., 103, 6097-6107, 1998.

Park, K., Kittelson, D., and McMurry, P.: Structural properties of diesel exhaust particles measured by transmission electron microscopy (TEM): relationships to particle mass and mobility, Aerosol Sci. Technol., 38, 881-889, 2004.

Petters, M. D. and Kreidenweis, S. M.: A single parameter representation of hygroscopic growth and cloud condensation nucleus activity, Atmos. Chem. Phys., 7, 1961-1971, doi:10.5194/acp-71961-2007, 2007.

Petters, M. D. and Kreidenweis, S. M.: A single parameter representation of hygroscopic growth and cloud condensation nucleus activity - Part 2: Including solubility, Atmos. Chem. Phys., 8, 6273-6279, doi:10.5194/acp-8-6273-2008, 2008.

Petzold, A. and Schonlinner, M.: Multi-angle absorption photometry - a new method for the measurement of aerosol light absorption and atmospheric black carbon. J. Aerosol Sci., 35, 421-441, 2004.

Petzold, A., Schloesser, H., Sheridan, P. J., Arnott, W. P., Ogren, J. A., and Virkkula, A.: Evaluation of multiangle absorption photometry for measuring aerosol light absorption. Aerosol Sci. Technol., 39, 40-51, 2005.

Pringle, K. J., Tost, H., Pozzer, A., Pöschl, U., and Lelieveld, J.: Global distribution of the effective aerosol hygroscopicity parameter for CCN activation, Atmos. Chem. Phys., 10, 52415255, doi:10.5194/acp-10-5241-2010, 2010.

Roberts, G. C. and Nenes, A.: A continuous-flow streamwise thermal-gradient $\mathrm{CCN}$ chamber for atmospheric measurements, Aerosol Sci. Technol., 39, 206-221, 2005.

Rose, D., Gunthe, S. S., Mikhailov, E., Frank, G. P., Dusek, U., Andreae, M. O., and Pöschl, U.: Calibration and measurement uncertainties of a continuous-flow cloud condensation nuclei counter (DMT-CCNC): CCN activation of ammonium sulfate and sodium chloride aerosol particles in theory and experiment, Atmos. Chem. Phys., 8, 1153-1179, doi:10.5194/acp-8-11532008, 2008.

Saxena, P. and Hildemann, L. M.: Water-soluble organics in atmospheric particles: A critical review of the literature and application of thermodynamics to identify candidate compounds, J. Atmos. Chem., 24, 57-109, 1996.

Shilling, J. E., King, S. M., Mochida, M., Worsnop, D. R., and Martin, S. T.: Mass spectral evidence that small changes in composition caused by oxidative aging processes alter aerosol CCN properties, J. Phys. Chem. A, 111 (17), 3358-3368, 2007.

Shulman, M. L., Jacobson, M. C., Carlson, R. J., Synovec, R. E., and Young, T. E.: Dissolution behavior and surface tension effects of organic compounds in nucleating cloud droplets, Geophys. Res. Lett., 23, 277-280, 1996.

Sjogren, S., Gysel, M., Weingartner, E., Alfarra, M. R., Duplissy, J., Cozic, J., Crosier, J., Coe, H., and Baltensperger, U.: Hygroscopicity of the submicrometer aerosol at the high-alpine site Jungfraujoch, $3580 \mathrm{~m}$ a.s.1., Switzerland, Atmos. Chem. Phys., 8, 5715-5729, doi:10.5194/acp-8-5715-2008, 2008.
Sjogren, S., Gysel, M., Weingartner, E., Baltensperger, U., Cubison, M. J., Coe, H., Zardini, A., Marcolli, C., Krieger, U. K., and Peter, T.: Hygroscopic growth and water uptake kinetics of twophase aerosol particles consisting of ammonium sulfate, adipic and humic acid mixtures, J. Aerosol Sci., 38, 157-171, 2007.

Sorjamaa, R., Svenningsson, B., Raatikainen, T., Henning, S., Bilde, M., and Laaksonen, A.: The role of surfactants in Köhler theory reconsidered, Atmos. Chem. Phys., 4, 2107-2117, doi:10.5194/acp-4-2107-2004, 2004.

Stokes, R. H. and Robinson, R. A.: Interactions in aqueous nonelectrolyte solutions. I. Solute-solvent equilibria, J. Phys. Chem., 70, 2126-2130, 1966.

Stroud, C. A., Nenes, A., Jimenez, J. L., DeCarlo, P. F., Huffman, J. A., Bruintjes, R., Nemitz, E., Delia, A. E., Toohey, D. W., Guenther, A. B., and Nandi, S.: Cloud activating properties of aerosol observed during CELTIC, J. Atmos. Sci., 64, 441-459, 2007.

Topping, D. O., McFiggans, G. B., and Coe, H.: A curved multicomponent aerosol hygroscopicity model framework: Part 1 - Inorganic compounds, Atmos. Chem. Phys., 5, 1205-1222, doi:10.5194/acp-5-1205-2005, 2005.

Twomey, S.: Influence of pollution on shortwave albedo of clouds, J. Atmos. Sci., 34, 1149-1152, 1977.

Vestin, A., Rissler, J., Swietlicki, E., Frank, G. P., and Andreae, M. O.: Cloud-nucleating properties of the Amazonian biomass burning aerosol: Cloud condensation nuclei measurements and modeling, J. Geophys. Res., 112, D14201, doi:10.1029/2006JD8104, 2007

Weingartner, E., Burtscher, H., and Baltensperger, U.: Hygroscopic properties of carbon and diesel soot particles, Atmos. Environ., 31, 2311-2327, 1997.

Weingartner, E., Nyeki, S., and Baltensperger, U.: Seasonal and diurnal variation of aerosol size distributions $(10<\mathrm{D}<750 \mathrm{~nm})$ at a high-alpine site (Jungfraujoch $3580 \mathrm{~m}$ asl), J. Geophys. Res., 104, 26809-26820, 1999.

Weingartner, E., Gysel, M., and Baltensperger, U.: Hygroscopicity of aerosol particles at low temperatures. 1. New low-temperature H-TDMA instrument: Setup and first applications, Environ. Sci. Technol., 36, 55-62, 2002.

Zhang, Q., Jimenez, J. L., Canagaratna, M. R., Allan, J. D., Coe, H., Ulbrich, I., Alfarra, M. R., Takami, A., Middlebrook, A. M., Sun, Y. L., Dzepina, K., Dunlea, E., Docherty, K., DeCarlo, P. F., Salcedo, D., Onasch, T., Jayne, J. T., Miyoshi, T., Shimono, A., Hatakeyama, S., Takegawa, N., Kondo, Y., Schneider, J., Drewnick, F., Borrmann, S., Weimer, S., Demerjian, K., Williams, P., Bower, K., Bahreini, R., Cottrell, L., Griffin, R. J., Rautiainen, J., Sun, J. Y., Zhang, Y. M., and Worsnop, D. R.: Ubiquity and dominance of oxygenated species in organic aerosols in anthropogenically-influenced Northern Hemisphere midlatitudes, Geophys. Res. Lett., 34, L13801, doi:10.1029/2007GL029979, 2007. 